States and Ontological Security: A Historical Rethinking ${ }^{\mathrm{i}}$

Ayşe Zarakol

University of Cambridge

az319@cam.ac.uk

FORTHCOMING IN COOPERATION \& CONFLICT 


\section{States and Ontological Security: A Historical Rethinking}

\section{Introduction}

'Ontological security' comes from having a consistent sense of 'self,' and having that sense affirmed by others, an outcome that requires shared ontological structures. This concept was imported nearly two decades ago into the IR literature from Psychology and Sociology, and later used to argue that states, just like individuals, care about their ontological security and act in ways in order to maintain a stable sense of 'self' (e.g. Mitzen, 2006b). Some have objected to the transfer of the concept into IR by countering that states do not have 'selves' ${ }^{2}$ and therefore cannot 'care' about ontological security. This objection, while not entirely implausible, implicates 'the state as a unitary actor' trope in IR altogether. If states do not have selves, they also cannot 'care' about their physical survival ${ }^{3}$ or be thought of as purposeful rational agents. Without ontological security, the self cannot know where it begins and ends, and what is essential to the body (and its survival) can only be defined by the self. Individuals with Body Integrity Identity Disorder (BIID), for instance, find perfectly healthy limbs to be superfluous and prefer amputation as a pathway to a more accurate bodily expression of the self. ${ }^{4}$ In other words, any IR theory that works with an assumption that states care about state survival implicitly assumes the state to be an ontological security-seeking agent. ${ }^{5}$ However, until the recent emergence of the ontological security literature in IR (See e.g. Huysmans, 1998; McSweeney, 1999; Lang Jr., 2002; Manners, 2002; Kinnvall, 2004, 2006; Mitzen 2006a, 2006b; Steele, 2007, 2008a, 2008b; Zarakol, 2010; Lupovici, 2012; Browning and Joenniemi, 2013; Rumelili, 2013, 2015; Subotic, 2015) ${ }^{6}$, the ontological security dimensions of state agency remained unproblematised. ${ }^{7}$ The growth of this literature, by making explicit what used to implicit, now gives us an opportunity to pause and wonder why the state behaves in this manner, whether it always has and will continue to do so.

The relationship between the state and ontological security seeking is difficult to parse analytically, however, because our 'modern' understanding of the State often assumes that the state provides ontological security, i.e. acts as a shared ontological structure for citizens' security: 'Ultimately the legitimacy of the state rests on its capacity to provide order-not a particular content of order but the function of ordering, of making life intelligible' (Huysmans, 1998: 242). Put another way, 'states' that do not perform this type of ordering function do not seem sovereign in the sense we understand the word today. They do not claim a monopoly on the legitimate use of force within a given territory (if we go by the Weberian definition of the state); or separate friends from enemies and decide exceptions (if we go by the Schmittian one). The modern State (but not necessarily all of the contemporary states of the present moment) is thus understood to be an ontological security providing institution for its citizens. Arguably, it is for that reason we can conceive of it as an ontological security-seeking agent itself. For good portions of human history, it was not possible to think of political authority quite in this manner, which is precisely the reason why we have some difficulty recognising many (though not all) polities predating modernity as 'states'. ${ }^{8}$ This raises the intriguing possibility that sovereignty itself cannot be thought of as separate from such an institutional monopolisation of the provision of ontological security-i.e. it is possible that institutions of political authority that do not offer the people a 
secure ontological framework may not be thought of as truly sovereign, even if they have exclusive territorial control.

The recognition of the historical contingency of the relationship between political authority and ontological security would have significant implications for the discipline of IR. First, this suggests that the state as an ontological security providing — and therefore seekinginstitution is not a timeless element of the human condition but rather a version of political authority which grew out of particular historical and sociological conditions of a particular time in a particular place, i.e., in Western Europe. ${ }^{9}$ Second, this recognition would support the observation that ontological security needs of a given populace may be met by other institutions besides those commanded by political authority; as will be discussed below, historically, religious authority has been the most likely other candidate for maintaining this type of ontological structure. ${ }^{10}$ This further implies that we can compare and contrast societies at any given time and across space by focusing on the primary institutional providers of ontological security rather than assuming the priority of one type of institution over another. In other words, the concept of ontological security may offer one of the rare bridges of commensurability for societies along temporal and spatial lines. If the need for ontological security is indeed a basic human need, then we can ask of any human community how its ontological security needs are/were being met and compare communities along this axis. In this way, the use of the concept of ontological security can allow the discipline to leave behind its twentieth century assumptions about the universality of the state's central role in world affairs, and thus enable us to speak to sections of the past and the future that may be radically different than the one posited by mainstream theories in IR.

In the following, I discuss various possible institutional configurations for provisions of ontological security by abstracting from particular moments in history, sketching three different arrangements that dominated during specific periods of world affairs. This is not meant to be an exhaustive survey of all possible such institutional configurations that have existed but rather a theoretical exercise meant to challenge the automatic equivalency we assume ${ }^{11}$ to be present between modern states and ontological security provision/seeking. This exercise contributes to the growing ontological security literature ${ }^{12}$ in several significant ways. First, it suggests that the ontological security literature should be linked more explicitly to debates about state sovereignty ${ }^{13}$ and highlights a few preliminary avenues doing so by linking the variation in the exercise of sovereignty with the institutional arrangements for ontological security provision. Second, it raises the possibility that the individual-centric (e.g. Kinnvall 2004, 2005) vs. the more state-centric (e.g. Mitzen 2006a, 2006b) emphases to the deployment of the ontological security concept in IR may have a temporal dimension in addition to an analytical one. Finally, it illustrates an additional value of the concept of ontological security via the avenue it offers for comparison between religious and political arrangements in different societies. In sum, this article demonstrates that the use of the concept of ontological security in IR does not have to be limited to a synonym for 'state identity'.

\section{Ontological Security as a Point of Commensurability across History and Space}

In The Divided Self (1969), R.D. Laing described the ontologically secure agent as someone who has 'a sense of his presence in the world as a real, alive, whole, and, in a temporal sense, a 
continuous person' (p. 39) and noted that if ontological security is absent, 'the ordinary circumstances of everyday life constitute a continual and deadly threat' (p. 40). Anthony Giddens further defined ontological security in The Consequences of Modernity (1990) as 'the confidence that most human beings have in the continuity of their self-identity and in the constancy of the surrounding social and material environments of action' (p.92). Though the concept itself is of relatively recent vintage, there are reasons to believe that ontological security is a basic human need: 'To be ontologically secure is to possess, on the level of the unconscious and practical consciousness, "answers" to fundamental existential questions which all human life in some way addresses' (Giddens 2008, 65). Giddens himself suggests that the search for answers for ontological security starts after an infant develops understanding an external reality outside of him/herself. For the purposes of this essay, therefore, I assume ontological security to be a universal need shared by all human beings.

Taking inspiration from Giddens (1991) but also Kinnvall (2004), I further posit that in any given society human beings can derive ontological security from two types of sources: institutionalised and non-institutionalised. The latter involves everyday situations, environments and interactions - to the extent that everyday practices are stable and familiar, (individual) persons will feel ontologically secure in them. Institutionalised sources of ontological security involve the provision and management of an ontological framework that makes sense of the self in the context of the larger existential questions that an (individual) may face during periods of stability, e.g. 'What happens after death?', 'What is the meaning of life?', 'Why do bad things happen to good people?', as well as during periods of crisis that make it difficult to derive security from familiar routines and environments. As will be discussed below, the institutional sources for ontological security may be religious or secular - there are examples for both in human history. Whatever their origin, institutional providers of ontological security almost invariably must make a claim to sovereignty (or monopoly), however, because the absence of such a claim would be ontologically threatening to those who are supposed derive comfort from that institution. To put it in simpler terms, it would be difficult to derive much ontological security from a framework provided from an institution that did not claim to be sovereign in this sphere: if the answers given by an institution to the questions noted above are 'Who knows...', 'We do not know', etc., it is unlikely that individuals will be relying on the ontological framework of that institution for their security. This suggests that if political authority gets into the ontology 'business' by itself (as opposed to acting as a franchisee of a particular religious authority) it must make a case for its own ontological certitude. This further implies that the reason why we have been able to think of modern states as ontological security seeking agents themselves in IR is precisely because the modern state's claim to be an ontological security provider for its citizens drives it to seek stable relationships within the modern state system. ${ }^{14}$

If the goal is to imagine possible points of equilibrium for a given society in terms of the provision of ontological security for its members, it would seem that the main points of variation would be between 1) non-institutionalised vs. institutionalised sources of ontological security, and 2) the many possible different arrangements in each category. Given human ingenuity and imagination, the universe of possible configurations of the sources of ontological security therefore is almost infinite, or seemingly so. For purposes of simplification, in this essay, I will treat the non-institutionalised sources of ontological security as a lump category (that either takes 
more or less space in a particular configuration). This will allow me to focus on institutionalised sources of ontological security (and by implication, on particular institutions as potential ontological security seeking agents themselves). Within this category, I will further limit institutionalised sources to those commanded by the main political authority and/or those commanded by the main religious authority. This is to allow for the broadest possible comparison across time and space. The question of whether other types of institutions can be sources of ontological security is very interesting but one I will have to leave aside for space considerations.

Given these limitations, it is possible to ask for any given society: 1) what is the primary source of ontological security for the members, and is it institutionalised? 2) If yes, is the main institutionalised source of ontological security political or religious (or both)? and 3) What is the main competition/challenger of this particular arrangement? Next I discuss some representative arrangements for ontological security provision (OSP) as they have manifested in history.

First a caveat, however: some parts of the argument, especially about Types B and C, may be familiar to anyone versed in the literature on religion in $\mathrm{IR}^{15}$; nevertheless, looking at even well-known examples through a ontological security oriented framework has a benefit. As noted by Shakman Hurd (2015b), the study of religion is more popular than ever in IR but this has not necessarily translated into a better understanding of religion, especially in public debates that remain fixated on Islam. The problem, as I see it, is that discussions of different religions in the contemporary international order either treat all religions as essentially the same or essentialise only a particular religion (usually Islam) as problematic. The latter usually manifests as a xenophobic strain in domestic political debates and is easily dismissed. It is the former approach that is more common in academic analyses. That any kind of generalizing academic discourse about religion or culture gives fodder to discrimination is well understood; ${ }^{16}$ even mentioning the possibility of differences (whatever they may be) among identity categories runs the danger of reproducing the social hierarchies in the international system. Yet from a scholarly perspective it is also problematic to ignore differences if they do exist. Hence, many ${ }^{17}$ are still looking for more productive ways of theorising about religion. The concept of ontological security, as applied to institutional providers, offers IR another promising way of thinking through the important questions about cultural and religious differences in world politics while avoiding the dual pitfalls of unwarranted smugness and false equivalence. With all that out of the way, let us now take a look at some ontological security provisions (OSPs) as they have manifested in history.

\section{OSP Type A: No Institutional Competition/ Hyper-sovereignty ${ }^{18}$}

Even the question of whether an institution of religious or political authority is the primary ontological security provider in a given society presumes that these institutions are distinct, which in fact is not universally true. There were in fact periods when the opposite was the norm in human affairs: the period before the Axial Age, for instance. The Axial Age was a period roughly between $800 \mathrm{BCE}$ and $700 \mathrm{CE}$, when several high cultures of Eurasia (e.g. in what is present day Greece, Israel, India, China, Iran etc.) underwent some major changes: 'an increasing human reflexivity', 'an increasing historical consciousness and... a sense of relative contingency', 
'an increasing awareness of the malleability of human existence, of the potentials of human action and human agentiality within the bounds of human mundane temporality', 'an elaboration of more reflective cosmologies' and 'an articulation... of such cosmologies in terms... of their textual inscription and the emergence of a set of rules for the authoritative interpretation of such texts' (Wittrock, 2005: 66; see also Arnason, Eisenstadt and Wittrock, 2005; Goldstone, 1998). It is this earlier transformation, which paralleled the later transition into modernity in some ways, that made it even possible to think of religion and politics as distinct spheres.

In pre-Axial societies, by contrast, religion was 'a system that [was] ineradicably inscribed in the institutional, linguistic, and cultural conditions of a society - a system that [was] not just coextensive with culture but practically identical to it' (Assmann 2010, 2). In such communities, political authority and religious authority were intertwined. In this particular configuration (more common in pre-Axial societies), political authority (quite recognisable, in fact, as the Egyptian 'State') is the primary ontological security provider (OSP) for its population and does not face other institutional challengers in this realm, due to the fact that political and religious authority are one and the same. 'In Egypt, justice is a divine idea, but law and laws are a human institution. They are therefore the prerogative of the king, whose role it is to decree and implement them, and also to suspend them in cases where clemency is granted' (Assmann, 2010: 52). In other words, the Egyptian Pharaoh ${ }^{19}$ decided exceptions; he is almost recognisable as sovereign in the Schmittian sense.

The main internal challenge to the Ancient Egyptian 'state as religion' ontological security arrangement came from non-institutionalised sources, as ordinary Egyptians started becoming more independent from the state-religion (as one and the same thing) and started developing aspects of what we now call 'individuality'. For example, during the Middle Kingdom, there emerged the notion of the heart as a new symbol of personhood and of moral responsibility (Assmann, 2005: 141). This 'was caused by a severe disappointment in the political sphere', and this crisis of faith in the political order was followed by another significant development, i.e., 'the appearance of a religious trend, which Egyptologists call "personal piety", where individuals form special relationships with certain deities' (142) outside 'the official institutions of cult and temple' (145).

The Egyptian 'state' did not let these challenges go unnoticed. What followed is known as the Amarna period (1353-1336 BCE), during which the pharaoh Akhenaten 'replaced the countless traditional cults with the cult of one and only Aten, the god of light and time' (144) and declared other deities as false. In the cosmology he proposed, only Akhenaten (and therefore 'the state') could act as 'the sole mediator between god and man' (144). During this period, all of the resources of Egypt were channelled to building a new capital city on a virgin site dedicated to the new cult - a monumental 'state-building' task that was accomplished in the span of half a decade. The Amarna period can therefore be seen as an attempt by the Egyptian state to rebuild itself by restoring its claim to be the main ontological security provider for its people. ${ }^{20}$ Akhenaten was not successful, however. Soon after his death, the new state religion and the new capital were abandoned, traditional deities were reintroduced, and personal piety continued to increase throughout Egyptian society. Later these developments would give way for a different type of challenge to the Egyptian 'state', as illustrated in the story of Exodus and subsequent 
renunciation of all political authority claims on ontological security provision (see the next section below).

Before moving onto the discussion of alternative configurations for OS provision, let me note that while the Egyptian arrangement discussed above was more representative of the preAxial age of primary religions, it is not impossible to imagine scenarios in other periods in which institutions of political and religious authority are fused and thereby monopolise the provision of ontological security together. Such is ultimately a claim of 'hyper-sovereignty': all institutionalised sources for ontological security provision are centralised under one heading. ${ }^{21}$

Another prominent historical manifestation of this particular configuration, for example, is the original 'Islamic State' of the sixth and seventh centuries BCE. Though the emergence of Islam belongs in the post-Axial Age, unlike Judaism or Christianity, it originated without a bifurcation between politics and religion: 'As believers and as citizens [Muslims] were members of the umma and ruled by the Prophet, thereafter by his successors' (Crone 2010, 13). This difference can be attributed to the fact that these other religions originated in environments of existing and complex political organizations, and therefore were formulated against particular prior institutions with claims to ontological security provision. Islam, by contrast, originated in an environment (the desert, nomadic tribes etc.) with no complex institutions or well-defined political structure. Such institutions were created after the emergence of Islam. Hence 'Muslims started with the opposite conviction [of the Judeo-Christian trajectory]: truth and power appeared at the same times in history and regulated the same aspects of life, more precisely all of them' (Crone 2010,16). In a broad historical sense, this initial and extreme fusion of political and religious authority in Islam was a very short-lived arrangement (not surprising given the broader post-Axial environment favouring the separation of political and religious spheres). Nevertheless, the example is well worth remembering, not the least for the inspiration its serves for the current 'Islamic State'. I'll return to the connection in the conclusion.

\section{OSP Type B - Institutional Competition - Religious Authority as the Primary OSP/Divisible Sovereignty ${ }^{22}$}

One of the consequences of the aforementioned Axial transformation was the growing autonomy of the transcendental sphere from the mundane, and the religious authority from the political. This created a competition between political authority and religious authority, especially in the realm of ontological security provision. In most post-Axial contexts, the institutions of religious authority gained the upper hand, though the extent of their supremacy as OSP seems to have varied. Let us now briefly look at few such arrangements.

Judaism, for instance, was articulated very much in direct opposition to the (Egyptian) 'state': 'By leaving Egypt, Israel separates itself from a political system, which is denounced as false, oppressive and humiliating' (Assmann, 2005: 149) and 'in the same way that the people represent themselves from political oppression, God also 'emancipates' Himself from political representation. Religious salvation becomes thus the exclusive competence of God' (150). Judaism took an explicitly anti-political character that argued for severe limits on political power and meddling in ontology. Idolatry was prohibited, representation of God through magic was disallowed; these changes undermined the civic function of ritual and the bonding that such rituals created between the political authority and the people. The divine sphere thus became 
independent of political institutions (Assmann, 2005: 153). Political authority was now defined in a way that was subservient or irrelevant to religious authority, and thus stripped of its ability to provide ontological security (except as an affirmation of the religious authority's claims ${ }^{23}$ ). Justice and lawgiving became god's business: "only in the context of a religion in which god appears as both a lawgiver and judge does the thought first become thinkable that man's judgment and god's can diverge significantly' (Assmann, 2010: 55). Essentially, the political authority was no longer sovereign, at least in the sense many understand the concept today. This is because by codifying (and putting in writing) God's law, secondary religions ${ }^{24}$ of the post-Axial Age, such as Judaism, rendered God's laws eternal and absolute while labelling man's laws as inferior and arbitrary: 'By theologizing the law and elevating it to the status of divine law, monotheism freed people from the illusion that without a king to dispense them justice, they would be at one another's throats. With that, the hitherto unquestioned alliance of justice and the state (and of kingship and salvation) comes to an end' (56).

Though the rejection of the political as an avenue of salvation and enlightenment is particularly evident in the Biblical tradition, many other geographies had similar transformations. Even Islam, which emerged much later than most other secondary religions, and which had originally fused political and religious authority in the person of the Prophet and the office of the caliph (as discussed in the previous section), developed such a separation of the political and religious authority relatively early on in its history. Scholars disagree on exactly when this separation occurred, but even the most sceptical authors agree that by the late Umayyad period Sunni Islam had developed the notion of a separate religious authority as a check on the power of the caliph, partly as a response to the oppressive political power of the Umayyad caliphs: 'Within two centuries of the [original Islamic] conquests, the vast majority of Muslims thus found themselves ruled by caliphs whom they did not consider to be embodiments of right and wrong. They might grudgingly recognize them as legitimate, accepting them what one might call quasi-caliphs...or they might positively denounce them as kings and tyrants, but either way they could not model themselves on them. For guidance to salvation they had to look elsewhere' (Crone 2010, 42). In order to curb the excesses of caliphal rule, the opponents responded 'by withdrawing from caliphal control all matters of religious significance, above all the definition of God's law. This was the solution adopted by the future Sunnis...Caliphal power thus remained absolutist, but it affected politics alone' (Crone and Hinds, 2003: 108). Later, political authority was wielded not even by the caliph but rather by various kings and sultans, despite having been denounced in the early years of Islam as examples of profane corruption. Parallel to these developments was the emergence of a school of thought in the ninth century which argued that 'religious authority rested entirely on knowledge (ilm) of the Qur'an and Prophetic Hadith, not on high office, descent from the Prophet, superior reasoning, or (when they appeared) claims to special friendship with God. This had radical implications in socio-political terms. The truth was dispersed among the believers at large...the caliph was no different from any other Muslim in this respect' (Crone 2010, 128). In sum, at least in Sunni Muslim societies (until a much later period) ${ }^{25}$, all matters of law, justice and morality (and not just those pertaining to private matters) were not under the control of political authority but rather the ulema (religious authority): 'a ruler who has no say at all in the definition of the law by which his subjects have chosen to live cannot rule those subjects in any but a purely military sense' (109). This is a Type B OSP arrangement 
whereby the (ontological security) competition from the political authority has been all but eliminated (or nearly so).

In much of this, such Muslim communities were similar to the diaspora Jews as well as Hindu India, 'where brahmanic dominance similarly led to the formation of an all-embracing holy law withdrawn from royal control [and therefore] the state became practically redundant' (109). In these and other similar cases of Type B OSP arrangements, there is quite a distinct separation of material and ontological power. Political authority does not lack material strength but is almost entirely unable to position itself as the primary OSP. Subjects did obey such examples of political authority, but overall 'the prevailing attitude to [political] power was one of quietism: rulers must be obeyed whether they are right or wrong' (109). Such subjects do not derive ontological security from political institutions except in a non-institutionalised sense, i.e. their presence is part of an everyday routine. In Type B arrangements, politics and political authority become something to be endured or ignored rather than the alternative positive conceptions that obtained for example in Ancient Egypt as discussed above, or the Ancient Greek and Roman view of politics as virtue. In Type B societies, by contrast, political rule 'was thus something which sat on top of society, not something which was rooted in it' (110). By contrast, religion became instead 'an autonomous system that [could] emancipate itself from these conditions, transcend all political and ethnic borders, and transplant itself into other cultures' (Assmann 2010, 2).

When we turn to Medieval Europe, significant as the setting from which the ideal-typical arrangements of the modern state emerged, we find the broadly similar Type B pattern of the separation of the political and religious authority, with the Church having the better claim to be the main OSP. The differences that also existed here are worth underlining, however, for their probable role in later developments. To begin with, (by this point) the (Western) Christian tradition was different from the examples discussed above in that religious and political authority were cast on a slightly more equal footing, a situation justified by references to various scriptural passages such Matthew 22:21 ('Give to Caesar what is Caesar's and to God what is God's') and Luke 22:38 ('They said, Lord, behold, here are two swords. And he said unto them, it is enough') (Gray, 2007: 181). As a result, both the imperial and papal authorities during the Medieval period were in a competition in all realms, while at the same time 'both centers of authority, while making claims against the other, acknowledged that their counterpart had authority', reflecting 'the medieval concern that both powers, if not every officeholder, had divine legitimacy' (Gray, 2007: 183). In comparison to aforementioned examples, e.g. as in Islam, in which religious authority materially acquiesced to political authority in exchange for a nearly absolute monopoly of ontological security provision, the church in Medieval Europe had a degree of physical autonomy political rulers as well as its own political and economic interests. Similarly, unlike in Muslim polities, most rulers in Medieval Europe had some law-making powers that were not derived entirely from religious teachings. For all of these reasons, even though the primacy of the Medieval church as an OSP cannot be quibbled with, it also needs to be underlined that the gap between religious and political authority in terms of ontological power was less pronounced in Western Europe at the 'eve of modernity' than it was most elsewhere at the time. 
That the Church involved itself so-thoroughly within the mundane realm of human affairs as a competitor to political authority probably had something to do with its eventual 'defeat' in Europe. Just as the transition into 'the Axial Age' ushered in a period of human history where Type B arrangements-with religious authority as the primary OSP facing moderate to minimal competition from political authority in this realm - proliferated, the transition into 'modernity' made normative Type C arrangements - with political authority as the primary OSP facing moderate to minimal competition from religious authority (especially in Europe, where this arrangement originated). In this sense, the Axial transformation (more on this below) and the transition to 'modernity' are historical bookends of a long period (of almost two millennia in some cases) wherein major religions enjoyed a great deal of autonomy from the political authority and religious institutions had strong claims on ontological sovereignty.

Type $\mathrm{C}$ should be familiar to most readers and is in fact assumed to be a universal norm in IR, but let us briefly review the trajectory that led to this outcome. As discussed in the previous section, before modernity, Christianity, as interpreted by the Church, would have been the primary institutionalised source of ontological security in Europe for most people. During Medieval crises of profound ontological insecurity, such as the Black Death, religious institutions and authority rather than kings played pivotal roles (e.g. as in the Inquisition) precisely as a result of this positioning (see e.g. Moore 2006).

The Reformation changed this dynamic: 'First, the split in the church removed the "awe" of the spiritual institution'; second, both the Church and Reformers need the assistance of political authority which ended up nationalising the churches; and finally, 'the Reformed theology itself tended to promote this subordinated role of church to state' (185). Writing against the pitfalls of political corruption for the church and the devout, Luther argued that Christians 'should leave the kingdom of earth to any one who wants to take it' (Luther 1523, as quoted by Gray, 2007: 186). Though this sounds similar to the quietist renunciation of the political found also in other religious traditions as discussed in the previous section, Luther's formulation went a step further by simultaneously weakening religious authority in favour of individual empowerment: 'What, then, are the priests and bishops? I answer, Their government is not one of authority or power, but a service and an office; for they are neither higher nor better than other Christians' (Luther 1523, as quoted by Gray 2007: 186). In this way, Luther reduced 'the spiritual center to the individual's understanding of the "plain meaning" of the Scriptures, while leaving the state generally untouched, and thus unhindered' (189).

Space does not permit an extensive overview of this period, but it is well documented, even in IR, ${ }^{26}$ that the transition to modernity involved among other changes a fundamental shift in this dynamic in favour of the political authority vis-a-vis religious authority. The period between the Peace of Augsburg (1555) and the Thirty Years War (1618-48) was 'an age of confessionalization' wherein 'church (both Protestant and Catholic) and state cooperated for the twin purposes of social disciplining and state building, thus delineating the boundaries of various confessional entities in the Habsburg Empire' (Krstic 2011, 13; see also Schilling 2004). This dynamic, already underway, was moved further along with the formal recognition Westphalia brought to the cuins regio, eius religio principle. In the next century, religion served to legitimate 
growing state power (both ontologically and materially) in the form of absolute monarchy. It is in this period the rise of the modern state begins, at first manifesting as absolute monarchy legitimised by the notion of the divine right of kings (but no longer opposed by the church in their quest to be the sole-exception bearers): 'church has become a department of the state' in the form of a "re-paganized" political theology' (Gray 2007: 195).

Eventually, the Church lost even this downgraded position. The Reformation had opened the door to different readings of Scripture, which could be used 'to attack the divine right at its weak points' (195). Early modern political thought dwells extensively on the question of finding alternative legitimations of political authority, independent from prior religious ontologies. Not surprisingly, there was a growing emphasis on the 'individual' as the basis of that authority, which happened, perhaps not ironically, at the same time that more and more power was being centralized in the hands of the state. What is more interesting, for our purposes, is the fact that the post-Westphalia version of political authority, as it evolved, proved itself especially adept at competing with the institutions of religious authority in the realm of ontological security provision. With the rise of nationalism and growth of the modern bureaucratic apparatus, the Westphalian 'state' made possible the global proliferation of an arrangement very rarely seen in history: a situation in which people look to the structures of political authority as their main institutional source of ontological security and where religious authority is often hardly able mount an autonomous challenge.

What made this an unlikely outcome possible? There are reasons to believe that institutions of religious authority are more naturally suited to be the main OSP, since their raison d'etre is ontological ${ }^{27}$ (it is no accident, therefore, that both in Type A and Type B arrangements which prevailed through much of human history, they play significant roles). This unlikely outcome may have had something to do with the other changes associated with the transition to (Western) Modernity. It is generally accepted, for instance, that one of the consequences of European modernization was a decrease in physical threats and increase in psychological ones. Medieval Europe was characterised by higher levels of physical violence (even more than most other agrarian societies of that period) but lower levels of anxiety ${ }^{28}$ : 'To give way directly to impulses and not to take thought of the further consequences was...adequate to the social structure as a whole and therefore to "reality" (Elias, [1939] 2000: 405). Dangers therefore were more physical: 'The unarmed peasant lived in an abject condition. He was at the mercy of the armed lord to a degree that no person was exposed to others in the everyday life of later phases, when public or state monopolies of force had developed. The lord and master, on the other, the warrior, was functionally so little dependent on his inferiors, untrammelled in relation to them to an extent which surpassed by far the relative power surplus of any upper class in relation to lower classes at the later stages of social development'(Elias, [1939] 2000: 391). Though the extent of differences between contemporary and medieval European society is still vehemently debated, most scholars agree that this was a period characterised by lower degrees of selfreflexivity (see e.g. Bartelson, 2009: Ruggie, 1993: Goldstone 1988, 1998 etc.). Rationalisation and individualisation had not happened yet on a mass scale (nor were they promoted by the existing institutions). Where they existed, this was an exception rather than the rule. The average Medieval European person was not a purposeful, rational actor fixated with acquiring control over her inner and outer nature. He knew little of self-moulding, self-constraint, listening to their 
inner monologues, of reflexivity. According to Taylor (2007), in this period the self is better not thought of as bounded but rather as porous, operating at the whim of influences from the (enchanted) world.

Starting with the Renaissance, European society became increasingly more complex and more interdependent. The Renaissance society was one where old ties (and routines) were breaking down; people of different backgrounds were thrown together. For the first time (in some time) some degree of social mobility became possible. This meant two things. First, people were in increasing proximity to each other: 'For this reason the question of uniform good behaviour became increasingly acute, particularly as the changed structure of the new upper class exposed each individual member to an unprecedented extent to the pressure of others and of social control' (Elias, [1939] 2000). Second, station was not assumed to be given, which meant that self-moulding could play a role in relations to others: '.. they often thought themselves as free from the customs and traditional social roles...of their fathers. The men and women of the Renaissance regarded themselves as "creations" and as "works of art"; they believed they were able to "fashion" themselves" (Ringmar, 1996: 444 [citing Greenblatt, 1980]). Self-discipline became especially important in courtly society. There was relatively little physical violence (e.g. duelling was now forbidden) but there was intense competition for royal favour: 'Continuous reflection, foresight, and calculation, self-control, precise and articulate regulation of one's own affects, knowledge of the whole terrain, human and non-human, in which one acts, become more and more indispensable preconditions of social success' (Elias [1939] 2000: 398). The idea that one can change oneself, to acquire a new identity by watching his/her behaviour and impulses was not a widely held belief in Europe of this period before the advent of 'courtly' society of absolutism. After the decline of courtly society, the process of 'civilisation' continued through bourgeois society, and later, and to a lesser extent, working classes, widening the circles of identification and integration (see also de Swaan, 1995).

This 'civilising process ${ }^{29}$ eventually had a profound effect on the psychological make-up of the members of (European) society. Violence was increasingly externalised (or 'international'ised). Interactions with strangers became routinised due to the increasing selfregulation of all members of society. In other words, fear decreased, while anxiety increased. Elias expresses the difference as being similar to a difference between road systems, with the premodern society being similar to a country road of a simple warrior society with a barter economy. On such a road, 'there is very little traffic; the main danger which a person here has to fear from others is an attack by soldiers or thieves' (Elias, [1939]2000: 368). In such a society, people need to be constantly ready to fight and are understandably worried about their physical security. Modern society on the other hand, is more like the modern road in big city of our time with busy traffic, with minimal danger of physical attack. Yet modern traffic rules are 'founded on the assumption that every individual himself or herself regulating his or her behaviour with the utmost exactitude in accordance with the necessities of this network. The chief danger that people here represent for others results from someone in this bustle losing self-control' (Elias [1939]2000, p. 368). In modern society, primitive physical threats have been replaced to a large extent by the uncertainty caused by our relations to and dependence on other individuals. This does not mean violence has been eliminated, but our relationship to it has been transformed: 
'Modern society has become a risk society in the sense that it is increasingly occupied with debating, preventing and managing risks that it itself has produced' (Beck, 2006: 332). ${ }^{30}$

The anxieties particular to modernity stem from the fact that those of us in such societies have to live with the (implicit) realisation that we are responsible for the construction and consistency of our 'selves,' as well as the (terrifying) recognition that others around us are in the same situation. Can others be trusted to self-regulate? The problem is compounded by the demand created by modern society that we continuously interact with strangers whose personal or familial histories are virtually unknown to us (see also Gellner 1980). In modern society, primitive physical threats have been replaced by the uncertainty caused by our relations to and dependence on other individuals (Elias [1939]2000: 368). As a result, trust plays a large role in modern transactions, but trust 'presumes a leap to commitment, a quality of "faith" which is irreducible' (Giddens 2008, 27). Some of the strangers we have to trust are 'experts' without whom we cannot function in modern life and who are almost impossible to avoid altogether: 'The doctor, counsellor and therapist are as central to the expert systems of modernity as the scientist, technician or engineer' (Giddens 2008, 27). Scepticism of one group of experts often means replacing them with another group, e.g. doctors with acupuncturists.

'To be modern is to be part of a universe in which, as Marx said, "all that is solid melts into air"” (Berman 1982, 15; see also Harvey 1990, 11; Bauman 2000). (Western) modernity 'disembeds': 'casting members as individuals is the trademark of modern democracy. That casting, however, was not a one-off act: it is an activity re-enacted daily...Modernity replaces the heteronomic determination of social standing with compulsive and obligatory self-determination' (Bauman 2000, 31-32; see also Giddens 2008, 27-29). As a result, modernity is marked by high degrees of reflexivity: most aspects of life are susceptible to revision in light of new information (Giddens 2008, 29). This reflexivity 'extends into the core of the self' (46). Some experts, such as therapists, help the individual feel less 'alone in a world in which she or he lacks the psychological supports and the sense of security provided by more traditional settings', which are absent because modernity has replaced the 'protective framework of the small community and tradition... with much larger, impersonal organisations' (Giddens 2008, 47). In contrast to traditional systems where transitions were ritualised as rites of passage, in modernity, changes in the self have 'to be explored and constructed as part of a reflexive process of connecting personal and social change' (46). This puts many demands on the individual, who may have the option to turn to religion, but does not have the choice to avoid the ontological security structure put in place by the modern state. From the design of the education system to the certification of experts (and of even religious institutions in many cases), in modernity the political authority as 'the state' has all but monopolised the insitutionalised provisions of ontological security.

In other words, political authority became (as 'the state') the main institutionalised OSP in an environment where increasingly 'disembedded' individuals needed to be told which strangers were enemies and which were friends, and which experts were to be trusted and which were just quacks. Indeed, the recognition that a centralised political authority has to underwrite the trust needed for such an environment to function goes back to early Modern thought (see for instance Hobbes' Leviathan). It has long been observed that modernization processes and the rise of the 'gardening ${ }^{31}$ nation-state as form of political authority are linked more than 
coincedentally (even though the modern trend towards individualization would indicate otherwise at first glance): 'modernity produces certain distinct forms, of which the most prominent is the nation state...modern states are reflexively monitored systems, which, even if they do not 'act' in the strict sense of the term, follow coordinated policies and plans on a geopolitical scale' (Giddens 2008, 24).

\section{What's Next? Implications for the study of OS and the International Order}

In the previous section, I sketched out three OSP arrangements that dominated in different historical periods: Type A (wherein religious and political authority are fused and provide OS together), Type B (wherein there is institutional competition between religious and political authority, with religious authority having the stronger claim for OSP) and Type $\mathrm{C}$ (wherein there is institutional competition between religious and political authority, with political authority having the stronger claim for OSP). Type A arrangements were prevalent among the pre-Axial Age societies, Type B was common among post-Axial societies until modernity, and Type $C$ obviously dominates modern societies. This does not mean that all arrangements of any type are the same (some variations among types were discussed above ${ }^{32}$ ) or that there were no other types in a given period dominated by a particular type (we can easily point to Type A arrangements in later periods, for example). I also speculated (albeit superficially, due to space reasons) that the reason some pre-modern polities seem more recognizable as states may have something to do with the implications of the institutional arrangement of OSP for sovereignty. Type A and C political institutions are easily thought of as OS seeking agents themselves because they are so involved in OS provision; Type B political institutions, by contrast, are difficult to conceive of as corporate agents of any type (beyond the person and the needs of the actual 'individual' ruler). I conclude now by discussing the value of this typology for our understanding of the modern system.

The historical typology sketched above is worthwhile for the study of contemporary international relations for two main reasons. First, the discussion strongly suggests ${ }^{33}$ that though particular manifestations are highly variable, there are not infinite analytical categories for OSP configurations in any given society. A promising research direction, therefore, would be to study more closely how existing OSP arrangements in history were replaced by other arrangements in particular contexts, which can be illuminating for our times. Since there are good reasons to think that the nation-state may no longer be (or never really has been) meeting the ontological security needs of citizens (e.g. Kinnvall, 2004, 2005), and/or that the international order may itself undergoing serious transformations which empower non-state actors at the expense of sovereign states (e.g. Phillipps, 2010), the typology developed here can help us make sense of both the challengers to the nation-state in the realm of OSP and the sovereignty-related implications for the nation-state if it does lose its position as the primary OSP for contemporary society. The bird's eye view of history suggests a preliminary pattern: existing OSP arrangements are first threatened by the growth of and/or search for non-institutionalised sources of ontological security: the emergence of personal piety in Ancient Egypt, the notion of individualised readings of scripture after the Reformation etc. This search later gives way to an institutionalised challenger. The global turn away from the state and its political theology in the 
second half of the twentieth century has been well documented and extensively discussed; what is not clear is what, if anything, would replace the nation-state after its predicted demise. History cannot give definite answers but can help us to think more clearly and comparatively through different alternatives: e.g. ISIS seems to favour a Type A arrangement whereas al-Qaeda's Islamic Caliphate dream resembles Type B (not consciously, but because of their inspirations).

Second, the historical variations discussed above can help make sense of the existing and conflict-generating variations within the modern order. Further research in that direction can help answer why, for instance, of all religions Islam seems to be the most 'intractable' as a competitor of the modern state. This may have something to do with the particular Type B arrangements that were present in Muslim societies at the time of the transplantation of the Type $\mathrm{C}$ arrangement of the modern state. Such contrasts can be further shaded by closer attention to variations among Muslim polities. Geographical and cultural comparisons can be extended to other regions and traditions following the same OSP blueprint. Inspection of such historical and geographical variations in ontological security seeking through this typology also raises the possibility that the seemingly conflicting emphases within the existing OS literature on different units of analysis may actually stem not from theoretical disagreements but rather from the historical and socio-cultural contingencies presented by the particular cases under investigation. In this way, the historical long view can help us consolidate and accommodate the different strands of the OS literature in a productive way. 


\section{Notes}

i This article comes out of a long-term effort on my part to understand sovereignty and political authority outside of the Westphalian context. I have had the privilege of presenting my thinking on these issues (if not necessarily this particular version of the article) in several different institutions and benefited from the very generous audience feedback in all settings: Lund University, London School of Economics, University of Stockholm and Uppsala University. I am especially grateful to Catarina Kinnvall, Jennifer Mitzen, Jens Bartelson, Brent Steele, Christopher Browning, Stuart Croft, Iver Neumann, Tarak Barkawi, George Lawson, Kim Hutchings and James Morrison for their questions on earlier attempts to grapple with these arguments, without which this draft would have looked very different. I would also like to thank the editors and the anonymous referees at Cooperation \& Conflict for their excellent suggestions.

${ }^{2}$ It also should not be assumed that the notion that persons have 'selves' that make them 'individuals' is a universal one.

${ }^{3}$ Political rulers may worry about the loss of this or that piece of land, but that is something different from a territorial state caring about 'survival' (which is defined tautologically and therefore ontologically).

${ }^{4}$ For an overview of the psychological conditions that challenge our assumption that the boundaries of individual bodies and selves are unproblematic, see Ananthaswamy (2015)

${ }^{5}$ On this issue see especially Ringmar (1996). See also Meyer and Jepperson (2000) on the modernity of our conceptions of agency.

${ }^{6}$ Krolikowski (2008) and Lebow (2010) are more critical of the concepterson (2000) on the modernity of our conceptions of agency.

${ }^{7}$ Notwithstanding the various excellent contributions on the ontological status of the state. See e.g. Bartelson (1998, 2011, 2014), Ringmar (1996), Wendt (2004), Jackson (2004), Wight (2004),

Neumann (2004) etc.

${ }^{8}$ See e.g. Davies (2003).

${ }^{9}$ This should not be taken to imply, however, that a similar configuration would not or could not have arisen elsewhere.

${ }_{11}^{10}$ For another take on religion and ontological security, see Kinnvall $(2004,2005)$.

${ }^{11}$ Not everyone who writes about ontological security in international relations agrees that the term can be used to describe state concerns. See e.g. Kinnvall $(2004,2006)$ or Krolikowski (2008).

${ }^{12}$ See footnote 1.

${ }^{13}$ See e.g. Bartelson (2011, 2014); Kalmo and Skinner (2014); Schuett and Stirk (2015); also Krasner (1999).

${ }^{14}$ For space reasons I am unable to explore this angle much further, but the fact that we cannot apply state-centric IR theories to explain Medieval European politics for instance or other settings where Type B arrangements (see below) dominated is suggestive. I return to the issue of further avenues for research in the conclusion.

${ }^{15}$ See e.g. Sandal and James (2011), Shakman Hurd (2008, 2012, 2015); Snyder (2011); Fitzgerald (2011); Shah, Stepan and Toft (2012); Thomas (2005); Phillips $(2010,2011)$ etc.

${ }^{16}$ e.g. see Said (1979) and also Zarakol (2011). See also the political trajectory of Samuel

Huntington's argument about 'the clash of civilizations' and their use to justify the War on Terror.

${ }^{17}$ See footnote 9 for some examples.

${ }^{18} \mathrm{I}$ am borrowing this term from interfaith debates in Christianity (especially Calvinism) to denote a type of sovereignty that is beyond our current understanding of Weberian sovereignty.

${ }^{19}$ At least until the breakdown of the Old Kingdom.

${ }^{20}$ I am dwelling on this example precisely because this type of behaviour by states will become a rarity after the Axial Age until our time. I will return to Type A arrangements in the conclusion.

${ }^{21}$ Note that this is different from arrangements wherein either political or religious authority have been completely suppressed in favor of the other, which do not seem as stable as fusion arrangements, though the latter are much harder to create since the separation of politics and religion.

${ }^{22}$ See Bartelson (2011) on the divisibility of sovereignty.

${ }^{23}$ This is not the same situation as Type A where neither religous nor political authority have any autonomy from each other.

${ }^{24}$ The term 'monotheism' is relatively modern and is somewhat misleading in that some monotheistic conceptions allow for lesser deities - the main difference between 'monotheism' and 'polytheism' is 
better understood as the claim of the former to exclusive truth. 'Polytheistic' religions assumed the equivalence of deities. A better descriptor may be 'secondary religion': 'Primary religions evolve historically over hundreds and thousands of years within a single culture, society, and generally also language, with all which they are inextricably entwined. Religions of this kind include the cultic and divine worlds of Egyptian, Babylonian and Greco-Roman antiquity, among many others. Secondary religions, by contrast, are those that owe their existence to an act of revelation and foundation, build on primary religions, and typically differentiate themselves from the latter by denouncing them as paganism, idolatry and superstition. All secondary religions, which are at the same time book, world, and (with the possible exception of Buddhism) monotheistic religions, look down on the primary religions as pagan' (Assmann, 2010: 1).

${ }^{25}$ Some scholars (see e.g. Burak, 2013) are now arguing that Muslim polities underwent a significant change in this regard after the thirteenth century Mongol invasions. It seems that the Ottomans especially made an effort to bring the ulema under state control (through the institution of Seyh-ulislam) after the Mongol invasion, inspired partly by the Mongol idea of the sovereign, i.e., Chinggis Khan, as a divine legislator. Nevertheless this was at best an incomplete attempt. In nineteenth and twentieth centuries the Turkish state revisited its desire to bring religion under state control, but this move was inspired mostly by the evolving Western state model.

${ }^{26}$ See e.g. Blaney and Inayatullah (2000).

${ }^{27}$ The claim to be the main OSP comes especially naturally to secondary religions whose common denominator is not monotheism or 'the distinction between the One God and many gods but the distinction between truth and falsehood in religion, between the true god and false gods, true doctrine and false doctrine, knowledge and ignorance, belief and unbelief' (Assmann 2010, 2).

${ }^{28}$ Giddens (2008: 46) seems to disagree with this point, but when he says other ages besides our was characterised by high anxiety it is unlikely that he is referring to Medieval Europe. In any case, he also concedes that there is something qualitatively different in how anxiety is experienced in modernity.

${ }^{29}$ Elias' contention that the 'civilising process' must go hand-in-hand with the monopolisation of force and centralisation of authority has been challenged by number of scholars (see e.g. van Velzen, 1984; van Krieken, 1989, 2014) who point to examples to other 'civilizing processes' that developed in the absence of the modern state. Nevertheless, I think Elias' contention is still valid if read narrowly only to apply to Europe of this period. See van Krieken (1989).

30 'Life in the Middle Ages was hazardous, but there was no notion of risk and there doesn't seem in fact to be a notion of risk in any traditional culture. The reason for this is that dangers are experienced as given. Either they come from God, or they come from a world which one takes for granted' (Giddens 1999, 3).

31 'I suggest, further, that the bureaucratic culture which prompts us to view society as an object of administration, as a collection of so many "problems" to be solved, as "nature" to be "controlled", "mastered" and "improved" or "remade", as a legitimate target for "social engineering" and in general a garden to be designed and kept in planned shape by force (the gardening posture divides vegetation into "cultured plants" to be taken care of, and weeds to be exterminated), was the very atmosphere in which the idea of the Holocaust could be conceived, slowly yet consistently developed, and brought to its conclusion' (Bauman 1989 [2000], 18). See also Bauman (1991).

${ }^{32}$ Though some others were ignored because of space constraints. Totalitarianism, for instance, provides a puzzling case: is it an extreme variation of Type $C$ or another Type altogether?

${ }^{33}$ Because the typology is not exhaustive, this should be taken as a preliminary provocation. 


\section{References}

Ananthaswamy A (2015) The Man Who Wasn't There: Investigations into the Strange New Science of the Self. Boston: Dutton.

Anderson B (1991) Imagined communities: reflections on the origin and spread of nationalism. London: Verso. Arnason JP, SN Eisenstadt, and B Wittrock (eds.) (2005) Axial Civilizations and World History. Leiden: Brill.

Assmann J (2005) Axial 'Breakthroughs' and Semantic 'Relocations' in Ancient Egypt and Israel. In Arnason et al (eds.) Axial Civilizations and World History. pp. 133-156.

Assmann J (2010) The Price of Monotheism. Stanford, CA: Stanford University Press.

Bailey G and Mabbett I (2006) The Sociology of Early Buddhism. Cambridge: Cambridge University Press. Bartelson J (1998) Second Natures: Is the State Identical with Itself? European Journal of International Relations 4(3): 295-326.

Bartelson J (2009) Visions of World Community. Cambridge: Cambridge University Press.

Bartelson J (2011) On the Indivisibility of Sovereignty. Republics of Letters: A Journal for the Study of Knowledge, Politics, and the Arts 2(2): 85-94.

Bartelson J (2014) Sovereignty as Symbolic Form. London: Routledge.

Bauman Z (1991) Modernity and Ambivalence. Ithaca, NY: Cornell University Press.

Bauman Z (2000[1989]) Modernity and the Holocaust. Ithaca, NY: Cornell University Press.

Bauman Z (2000) Liquid Modernity. Cambridge: Polity Press.

Beck U (2006) Living in the world risk society. Economy and Society 35(3): 329-345.

Beck U (2009) Critical Theory of World Risk Society: A Cosmopolitan Vision. Constellations 16 (1): 3-22. Blaney D and Inayatullah N (2000) The Westphalian Deferral. International Studies Review 2(2): 29-64.

Bodin J (1576) The Six Books of the Commonwealth.

Burak G (2013) The Second Formation of Islamic Law: The Post-Mongol Context of the Ottoman Adoption of a School of Law. Comparative Studies in Society and History 55(3): 579-602.

Crone P (2010) God's Rule: Government and Islam. NY: Columbia University Press.

Crone P and Hinds M (2003) God's Caliph: Religious Authority in the First Centuries of Islam. Cambridge: Cambridge University Press.

Davies RR (2003) The medieval State, the Tyranny of a concept? Journal of Historical Sociology 16: 280 300.

Elias N (1939 [2000]) The Civilising Process. NY: Blackwell.

Fitzgerald T (2011) Religion and Politics in International Relations: The Modern Myth. London: Continuum, 2011.

Gellner E (1984) Nations and Nationalism. Ithaca, NY: Cornell University Press.

Giddens A (1991) Consequences of Modernity. Stanford, CA: Stanford University Press.

Giddens A (2008) Modernity and Self-identity: Self and Society in the Late Modern Age. Polity Press.

Goldstone J (1998) The Problem of the 'Early Modern' World. Journal of the Economic and Social History of the Orient 41(3): 249-284

Gray P (2007) Political Theology and the Theology of Politics: Carl Schmitt and Medieval Christian Political Thought. Humanitas XX, 1-2: 175-207.

Greenblatt S (1980[2005]) Renaissance Self-Fashioning: From More to Shakespeare. Chicago: University of Chicago Press.

Harvey D (1990) The Condition of Postmodernity. NY: Blackwell.

Hobbes T (1651) Leviathan. 
Huysmans J (1998) Security! What Do You Mean? From Concept to Thick Signifier. European Journal of International Relations 4(2): 226-255.

Jackson PT (2004) Hegel's House, or 'People are states too' Review of International Studies 30(2): 281-7.

Kalmo H and Q Skinner (2014) Sovereignty in Fragments: The Past, Present and Future of a Contested Concept. Cambridge: Cambridge University Press.

Kinnvall C (2004) Globalization and Religious Nationalism: Self, Identity, and the Search for Ontological Security. Political Psychology. 25(5): 741-67.

Kinnvall C (2006) Globalization and Religious Nationalism in India. NY: Routledge.

Kinnvall C (2015) Borders and Fear: Insecurity, Gender and the Far Right in Europe. Journal of Contemporary European Studies. Published online 13 Jul 2015.

Krasner S (1999) Sovereignty: Organized Hypocrisy. Princeton: Princeton University Press.

Krstic, T (2011) Contested Conversions to Islam Narratives of Religious Change in the Early Modern Ottoman Empire. Stanford, CA: Stanford University Press

Krolikowski A (2008) State Personhood in Ontological Security Theories of International Relations and Chinese Nationalism: A Skeptical View. Chinese Journal of International Politics 2(1): 109-33.

Laing RD (1969) The Divided Self. NY: Pelican.

Lang Jr. AF (2002) Agency and Ethics: The Politics of Military Intervention. Albany: SUNY Press, 2002.

Lebow RN (2010) A Cultural Theory of International Relations. Cambridge: Cambridge University Press.

Lichtheim M (1976). Ancient Egyptian Literature-A Book of Readings Volume II: The Old and Middle Kingdoms. Berkeley, CA: The University of California Press.

Lupovici A (2012) Ontological Dissonance, Clashing Identities, and Israel's Unilateral Steps towards the Palestinians. Review of International Studies 38(4): 809-33.

Manners I (2002) European [Security] Union: From Existential Threat to Ontological Security. IIS Working Papers, Copenhagen Peace Research Institute.

McSweeney B (1999) Security, Identity and Interests. Cambridge: Cambridge University Press.

Meyer JW and RL Jepperson (2000) The 'Actors' of Modern Society: The Cultural Construction of Social Agency. Sociological Theory 18(1): 100-20.

Mearsheimer J and Walt SM (2013) Leaving theory behind: Why simplistic hypothesis testing is bad for International Relations. European Journal of International Relations 19: 427-457.

Mignolo W (2012) The Darker Side of Western Modernity: Global Futures, Decolonial Options. Duke University Press.

Mitzen J (2006a) Anchoring Europe's Civilizing Identity: Habits, Capabilities, and Ontological Security. Journal of European Public Policy 13(2): 270-85.

Mitzen J (2006b) Ontological Security in World Politics. European Journal of International Relations 12(6): 341-70.

Moore RI (2006) The Formation of a Persecuting Society: Authority and Deviance in Western Europe 950-1250. 2d ed. Wiley-Blackwell.

Neumann I (2004) Beware of organicism: the narrative self of the state? Review of International Studies 30(2): 259-67

Philipps A (2010) The Protestant ethic and the spirit of Jihadism - transnational religious insurgencies and the transformation of international orders. Review of International Studies 36: 257-280.

Philipps A (2011) War, Religion and Empire. Cambridge: Cambridge University Press.

Reynolds S (1997) The Historiography of the Medieval State. In: Bentley M (ed.), A Companion to Historiography. Routledge, pp. 117-38. 
Ringmar E (1996) On the Ontological Status of the State. European Journal of International Relations 2(4): 439-66.

Ruggie JG (1993) Territoriality and Beyond: Problematizing Modernity in International Relations. International Organization 47(1): 139-174.

Rumelili B (ed.) (2015) Conflict Resolution and Ontological Security: Peace Anxieties. Routledge.

Sandal NA and James P (2011) Religion and International Relations theory. European Journal of International Relations 17(1): 3-25.

Schilling,H (2004) Confessionalization: Historical and Scholarly Perspectives of a Comparative and Interdisciplinary Paradigm. In Confessionalization in Europe, 1555-I700, J. M. Headley, H. J. Hillerbrand, and A. J. Papal (eds). Aldershot, U.K.: Ashgate. pp. 21-36.

Schmitt C ([1922]1985) Political Sovereignty: Four Chapters on the Concepts of Sovereignty. Schwab G (trans.). Cambridge, MA: The MIT Press.

Schuett R and PMR Stirk (eds.) (2015) The Concept of the State in International Relations. Philosophy, Sovereignty, and Cosmopolitanism. Edinburgh: Edinburgh University Press.

Shah TS, A Stepan and MD Toft, eds. (2012) Retbinking Religion and World Affairs. Oxford: Oxford University Press.

Shakman Hurd E (2008) The Politics of Secularism in International Relations. Princeton: Princeton University Press.

Shakman Hurd E (2012) International Politics after Secularism. Review of International Studies 38(5): 943961.

Shakman Hurd E (2015) Beyond Religious Freedom: The New Global Politics of Religion. Princeton: Princeton University Press, 2015.

Snyder J (ed.) (2011) Religion and International Relations Theory. NY: Columbia University Press.

Steele B (2007) Making Words Matter: The Asian Tsunami, Darfur, and 'Reflexive Discourse' in International Politics. International Studies Quarterly 51: 901-25.

Steele B (2008a) 'Ideals that were really never in our possession': Torture, Honor and US Identity. International Relations 22(2): 243-61.

Steele B (2008b) Ontological Security in International Relations. NY: Routledge.

Subotic J (2015) Narrative, Ontological Security, and Foreign Policy Change. Foreign Policy Analysis.

Published online on 23 January 2015: 1-18.

Taylor C (2007) A Secular Age. Harvard University Press.

Thomas S (2005) The Global Resurgence of Religion and the Transformation of International Relations. London: Palgrave Macmillan.

van Krieken R (1989) Violence, self-discipline and modernity: beyond the 'civilizing process'. The Sociological Review 37(2): 193-218.

van Krieken R (2014) Norbert Elias and Emotions in History. In: Lemmings D and Brooks A (eds.)

Passion, Power and Elias: Emotional Styles and Historical Change. London: Routledge.

van Velzen, HUE. (1984) The Djuka Civilization, Netherlands Journal of Sociology. 20(2): 85-97.

Wallerstein I, Collins R, Mann M, Derluguian G, and Calhoun C (2013) Does Capitalism Have a Future?

Oxford: Oxford University Press.

Wendt A (2004) The state as person in international theory. Review of International Studies 30(2): 289-316.

Wight C (2004) State agency: social action without human activity? Review of International Studies 30(2): 269-80.

William MJ (2008) (ln) Security Studies, Reflexive modernization and the Risk Society. Cooperation and Conflict 43(1): 57-79. 
Wittrock B (2005) The Meaning of the Axial Age. In: Arnason et al, (eds.) Axial Civilizations and World History. pp. 51-86.

Zarakol A (2010) Ontological (In)Security and State Denial of Historical Crimes: Turkey and Japan. International Relations 24: 3-33. 